\title{
Popular Science, Pragmatism, and Conceptual Clarity
}

Oliver Belas

\section{(2) OpenEdition \\ 12 Journals}

Electronic version

URL: http://journals.openedition.org/ejpap/514

DOI: 10.4000/ejpap.514

ISSN: 2036-4091

Publisher

Associazione Pragma

Electronic reference

Oliver Belas, « Popular Science, Pragmatism, and Conceptual Clarity », European Journal of Pragmatism and American Philosophy [Online], VI-1 | 2014, Online since 08 July 2014, connection on 16 March 2020 URL : http://journals.openedition.org/ejpap/514 ; DOI : https://doi.org/10.4000/ejpap.514

This text was automatically generated on 16 March 2020.

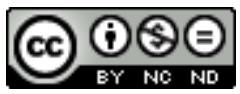

Author retains copyright and grants the European Journal of Pragmatism and American Philosophy right of first publication with the work simultaneously licensed under a Creative Commons AttributionNonCommercial-NoDerivatives 4.0 International License. 


\title{
Popular Science, Pragmatism, and Conceptual Clarity
}

\author{
Oliver Belas
}

\section{Introduction}

1 One of popular science's primary functions is to make what would otherwise be inaccessible, specialist knowledge accessible to the lay reader. But popular science puts its imagined reader in something of a dilemma, for one does not have to look very far to find bitter argument among science writers; argument that takes place beyond the limits of the scientific community: witness the ill-tempered exchanges between Mary Midgley and Richard Dawkins in the journal Philosophy in the late seventies and early eighties; or, from the mid-nineties, the surly dialogue of Stephen Jay Gould, Daniel Dennett, and others in The New York Review of Books (see below and Works Cited). These writers, communicators, and educators have played a significant part in the dissemination of evolutionary theory among non-specialists; they have shaped the understanding and use of genetic and evolutionary theory in non-scientific areas of academic study and cultural theory. Such vociferous disagreements as they have had are, then, of some public significance.

2 This article is not concerned primarily with the issue of influence, however. Rather, given the influence these and other writers have - and given their disputes with one another - I want to ask: when stark disagreement arises, how is the interested lay reader to make sense of such disagreement, when it is to these writers she looks for her scientific knowledge in the first place? How are we to engage with and evaluate the contributions of our teachers, when our teachers are engaged in fierce argument with one another?

3 To anticipate some of what is to follow: one problem for us "lay" readers is that some science writers get sidetracked by questions of who among them is "right" or "wrong." Such an eristic attitude, I suggest, mistakes just what is undertaken - and just what is at stake - in populist theorizing (as opposed to populist reporting in, say, the pages of New 
Scientist or Scientific American). In the context of pop science, questions of who is "absolutely right" or "absolutely wrong" are less interesting, and in many ways less important, than questions of who is most theoretically coherent and most convincing; of who, to use Nelson Goodman's vocabulary, offers us an account that seems to provide a "right fit" (Goodman 1978). The lay reader has little choice but to take the expertise of the science writer on trust (although this does not rule out the possibility of an expert being disavowed by most or even all of his scientific community, on scientific grounds). But, as we will see, the terms in which a science writer couches her narrative have little to do with scientific practice, per se. It is with these terms - what I shall call the concept metaphors of science writing - that the lay reader can engage critically; and it is here that pragmatism enters the stage.

4 My thesis is not that readers do not have to be scientists to make either heads or tails of popular science, so long as they are well versed in the various dialects of pragmatism. Rather, a pragmatist approach to our problem will help ground and justify not only my readings of Dawkins, Dennett, and Gould, but also my larger claim that there is plenty of critical space, as it were, in popular science for non-scientist readers.

5 If one aim of popular science is to educate Joe Public, then the genre aims to speak across boundaries - from the province of Professional Expertise to that of General Interest. Surely, then, such speech should not be one-way, but, rather, part of a conversation; ${ }^{1}$ surely, the occupants of General Interest's territory should find a way of taking their conversational turn. This article is just such an attempt.

6 I first establish a theoretical framework - which draws heavily on pragmatist philosophy - for the investigations of Dawkins, Dennett, and Gould that follow. Here, I also attempt to clear up what I think are some misapprehensions about our chosen mode of popular science and its appropriate disciplinary reach. A detailed concluding section explores the reasons for favouring the pop-science work of Gould over that of Dawkins. These "case studies" are shaped by the pragmatist framework outlined in earlier sections. ${ }^{2}$

\section{"Mission Creep." Generic "Purity" and the Function of Pop Science}

7 Robert Eaglestone (2005) has argued that popular science is characterized by an inbuilt "mission creep," whereby the claims of the genre, which by definition aspires to popular appeal, cease to be strictly scientific and encroach on the realms of the philosophical. Writers make their narratives attractive to lay readers "by showing why the subject [...] is relevant and meaningful for everyone, and this is usually done by making much bigger claims. [...] It is the very need for these more general claims that makes these popular science books unavoidably 'philosophical' in that they perforce and explicitly address 'what it is to be'." The issue here, then, is perhaps not so much the extra scientific pretensions of science, but the necessary pretensions of these books to address a wider readership.

8 Eaglestone refers several times to Dawkins, who states in The Selfish Gene that, thanks to Darwin (and the neo-Darwinist synthesis of genetics and evolutionary theory), "[w]e no longer have to resort to superstition when faced with the deep problems: Is there a meaning to life? What are we here for? What is man?" However, despite evolutionary 
theory's triumphs, students of the biological sciences tend to miss Darwin's “profound philosophical significance. Philosophy and the subjects known as 'humanities' are still taught almost as if Darwin had never lived." (Dawkins 2006, 1.)

The "extra-scientific pretensions" of these early remarks are clear enough, as are Dawkins's intentions to appeal to a "lay" as well as specialist readership (see Dawkins 2006, xxi, xxii); with Dawkins as our model, then, Eaglestone certainly seems to be right. But Eaglestone's comments are less true of the popular science genre per se than of Dawkins particularly. The problem with Dawkins, in the lines quoted above, is not that he falls foul of popular science's inbuilt "mission creep" (which for Eaglestone seems to be a problem of genre); the problem is Dawkins's disciplinary reductionism. As Dawkins imagines things, the humanities sit further up the disciplinary hierarchy, and are therefore logically dependent on the natural sciences for their foundations. Dawkins assumes that science, dealing with "bare facts," is more fundamental than the humanities, and that, consequently, other academic fields are somehow reducible to science (or, rather, his branch and brand of it): it is neo-Darwinism that can now answer the "big" questions, because it sits at the base of Dawkins's imagined disciplinary hierarchy.

But to be dissatisfied with Dawkins's hierarchism and reductionism is not to say that the blurring of boundaries between science and philosophy amounts to a real problem. For Quine, indeed, philosophy and science sat on the same continuum; philosophy simply operated to a greater degree of generality and abstractness (see, e.g., Quine 1963). For Richard Rorty (2009b), one of the oddities of philosophy is that it seems to exhibit, simultaneously, the hallmarks of what many would consider the arts and the sciences. And Daniel Dennett writes, with a certain commonsense directness, that "there is no such thing as philosophy-free science; there is only science whose philosophical baggage is taken on board without examination." (Dennett 1995, 21.) Turn, say, to John Dewey, and we find just the sort of grand philosophical claim, extrapolated from scientific theory, of which Eaglestone is so wary. For Dewey, Darwinism marks something very much like what we would now call, post Kuhn, a paradigm shift. But this paradigm shift completes a general conceptual shift to a perspective from which all our cultural life looks as though it is constantly in flux, as though it rests on foundations that are neither sure nor fixed (Dewey 1997).

11 In sort, "big" philosophical claims seem hardly to be avoided in works that deal with "big" scientific theories. (Note, too, that the examples given above are all made of science from the side of philosophy; would we be concerned to challenge these thinkers' extra-philosophical pretensions?) The injunction that pop science keep to itself and not mingle with philosophy is unrealizable; the careers of science and philosophy have been entwined for too long. ${ }^{3}$

The problem, then, is not that Dawkins, or indeed any pop-science writer, dares to make grand philosophical claims. The questions to be asked, rather, are: (1) are the disputants' grand claims clear, convincing; do they offer a "right fit;" or, to paraphrase Goodman (and to pull him out of context), do they manage to sell their ideas rather than prove them? $?^{4}$ (2) How is the non-specialist who relies on pop science for her scientific literacy to address (1)?

13 As we will see, arguments - often heated - between the neo- or ultra-Darwinist and Radical Science camps sometimes hinge on the terms in which the camps' respective arguments are couched. One prong of Dennett's attack on Gould, for example, is shaped 
by an attempt to "prove" Gould and Lewontin's notion of "spandrels" (summarized below) a nonsense; in Dennett's view, "spandrels" is an unworkable theory because it is founded on a duff analogy. I will argue, though, that Dennett misses his mark because the relationship between Gould's evolutionary theory and the architectural structure to which it is supposedly analogous does, in fact, hold good: it is, to borrow again from Goodman, a good fit, convincingly sold.

Before we turn to particular case studies, though, we will need to give some time to the idea of metaphor generally, for while both Midgley and Dawkins discuss "gene selfishness" as a metaphor, we will see that it is necessary to qualify with some care the sort of metaphor we are likely to be dealing with in popular science. Some detail will be needed; in the readings of Dawkins, Dennett, and Gould that follow, the problems and disputes we will tackle are very much over conceptions of metaphor itself, and writers' metaphorical language use. First, then, let us spend a little time on just some of what has been said of metaphor in general, as well as some of the sticking-points of these general accounts. I will turn briefly to remarks made by Rorty, Davidson, and Goodman.

\section{Rorty, Davidson, Goodman; Language and Metaphor ${ }^{5}$}

15 For Rorty, the ways in which we understand the world are constituted by language, which is fundamentally metaphorical: language does not take us closer to or further from things as they are "in themselves;" rather it makes and remakes the world as we understand or interpret it (Rorty 1989, 16). ${ }^{6}$ Language, as Rorty understands it, constitutes our hermeneutic relationship with a real world that is "out there," but is neither more nor less "really" or "truthfully" represented in, say, Einsteinian or Newtonian terms.

this view, then, a metaphor does not disguise yet somehow "contain" its litera meaning; it consists in the use of "familiar words in unfamiliar ways" (Rorty 1989, 18). Similarly, literal words are not transparent windows onto the world; they are simply metaphors that, through repeated and therefore increasingly comfortable use, have gained general currency. "Literal" words are metaphors, the metaphoricity of which we have forgotten.

17 Metaphors, in Rorty's sense, introduce new concepts or conceptual frameworks. The difference between literal and metaphorical language, then, is that the "literal uses of noises and marks are the uses we can handle by our old theories about what people will say under various conditions. Their metaphorical use is the sort which makes us get busy developing a new theory." (Rorty 1989, 17.) Rortyan metaphor is determined by its effects; but because language, for Rorty, neither moves us closer to nor further from the world in itself, metaphorical effect is measured by whether or not a new concept forces us to start re-theorizing or redescribe the world.

Rorty, of course, draws heavily on Donald Davidson, whose 1978 paper "What Metaphors Mean" has attained a level of notoriety among philosophers of language and theorists of metaphor. Metaphor is commonly understood, Davidson summarizes, as language that encodes "hidden" meanings, that says one thing while meaning another. But, he argues, "[w]e must give up the idea that a metaphor carries a message, that it has a content or meaning (except, of course, its literal meaning)" (Davidson 1978, 45). From the get-go, Davidson maintains that "metaphors mean what the words, in their most literal interpretation mean, and nothing more" $(1978,32)$. Metaphor, in Davidson 
$(1978,33)$, is not language that runs on the "dual tracks" of literal and hidden meanings, or of the said and the meant; it is an issue not of language and meaning, but of language in use.

19 A proper account of metaphor, Davidson believes, is simple enough. It requires not the formulation or discovery of rules for decoding metaphorical "meanings"; there are, in this account, neither such rules nor such meanings. What we might call the standard theories of metaphor - the dual track accounts - "mistake their goal," Davidson writes.

Where they think they provide a method for deciphering an encoded content, they actually tell us (or try to tell us) something about the effects metaphors have on us. The common error is to fasten on the contents of the thoughts a metaphor provokes and to read those contents into the metaphor itself (Davidson 1978, 45).

Davidson insists that metaphors belong to the "domain" of use, not of meaning. The unfamiliar, jarring quality of a well-chosen metaphor will lead us to make various associations, but there is no rule as to what these associations will be, and no necessary end to the stream of associations: "When we try to say what a metaphor 'means,' we soon realize there is no end to what we want to mention." (Davidson 1978, 46.) Here, a metaphor can denote no more than it does literally, but it can connote endlessly; metaphor functions in non-determinate, metonymic fashion.

\section{Goodman versus Davidson on Metaphor}

If it is hard, perhaps impossible, to specify in advance the limits of so-called "metaphorical meaning," then there is a sense in which Davidson is absolutely right about there being no necessary end to the associative power of metaphors. Nevertheless, it surely is possible objectively to misconstrue metaphors. There are boundaries to metaphorical meaning, but these boundaries are often unmarked; they may not be noticed until we are either up against or have strayed clear across them.

While certain paraphrases, interpretations, explanations of a particular metaphor are accepted as plausible, others are eventually rejected. This might be because: (1) some interpretations of metaphor seem to lead us more than reasonably far from an author's apparent or likely intentions. (2) We might reject interpretations because the literal, or "first," meanings of the metaphorical terms have been misunderstood. ${ }^{7}$ (3) A metaphor may be misconstrued because the object or referent under metaphorical description is not clearly known. ${ }^{8}$

In short, although one can never say with absolute certainty what the meaning of a metaphor is, few people object to the principle that some interpretations of metaphors are better, more reasonable, more plausible, or more useful than others. Just how apt our understandings or interpretations of metaphors are deemed to be will depend, in part, on linguistic communities - or, to put it in terms closer to Goodman (1978), the symbolic worlds ${ }^{9}$ - of which we find ourselves part. Synchronically or diachronically, the individual, of course, may operate in more than one community or world. Regardless, the point is this: in practice, metaphorical utterances - despite their infinite possibility - are unlikely to be quite so open-ended as Davidson suggests, as certain meanings, uses, interpretations will have greater or lesser sway in certain linguistic communities. 

literal and metaphorical meaning. Yet this is a line which seems, in most accounts Davidson's included - to be presupposed. Goodman makes the forceful point that if Davidson is even half-right to suggest that as metaphors pass from "life" to "death" their meanings do not change, then there must be something akin to a literal/ metaphorical difference that marks metaphors as such upon first utterance. If this is true, then it would seem to be the case that for Davidson, even as he argues against this distinction, metaphorical figures do mean otherwise than literal ones (Goodman 1979, 127).

Goodman, by contrast, wishes to guard the metaphorical/literal distinction that he believes Davidson fails to give up; indeed, he seems to take it as essential to the constitution and very possibility of metaphor. Goodman would have us use something like the following definition:

"The lake is a sapphire is literally false but metaphorically true" is true if and only if "

The lake is a sapphire is metaphorically true" is literally true. ${ }^{10}$

There is a significant difference for Goodman between an utterance being literally false but metaphorically true, and an utterance being merely false. Metaphorical utterances, then, require listener-interpreters to sort through permutations of literal/ metaphorical truth/falsity, just because metaphor involves the reassignment of labels (a claim close to Rorty's): "a metaphor is an affair between a predicate with a past and an object that yields while protesting," Goodman writes. "Where there is metaphor, there is conflict [...] Application of a term is metaphorical only if to some extent contraindicated." (1976, 69.) Goodman's definition also allows, for example, the possible literal and metaphorical truth of Frost's verse, "Two roads diverged in a yellow wood."

Goodman and Davidson are not so incompatible as may at first appear, however, if we turn from Davidson's account of metaphor and meaning, to his Tarskian conception of truth and meaning (see Davidson 1967, 1983). In Ways of Worldmaking (1978), Goodman's central claim is that our various symbolic systems - be they linguistic or not - structure our worlds in very real (one is tempted to say "very literal") ways. In claiming this, we can view Goodman as offering a sort of Davidsonian pluralism. Davidson's Tarskian definition of truth might hold good for both metaphorical and literal utterances, provided we know, pace Goodman, what symbolic world or system we are "in." Goodman's definition, as summarized above, can be restated as:

"The lake is a sapphire" is true in a given symbolic system if and only if in that system the lake is a sapphire. ${ }^{11}$

But if we take it for granted that all utterances occur in some given context (and possibly more than one context simultaneously), ${ }^{12}$ then we can further restate the above in Davidson's terms. The difference between definitions closer in form to either Goodman's or Davidson's is the difference between making the fuzzy notion of context explicit in the definition or taking it out and, therefore, for granted:

"The lake is a sapphire" is true [in a given symbolic system] if and only if [in that system] the lake is a sapphire.

In short, if we know "how" a sentence is intended (as metaphor, for example), then we will be able to determine its truth or falsity. ${ }^{13}$ Another way of putting this: provided that interlocutors understand and interpret the context of utterance in broadly overlapping ways, then Goodman's explanation of metaphor accommodates Davidson's 
theory of truth, and vice versa. Goodman does not cancel out Davidson's theory of metaphor; he simply does not go near it.

In a sense, then, metaphor is a matter of use, but not in the way Davidson suggests. Our ability to perform the literal/metaphorical truth-sortings suggested by Goodman depends on us rightly interpreting the context of use (that a sentence has been intended metaphorically and/or literally); but this does not mean that, in the context of a linguistic community or symbolic world, the meaning-effects of metaphors are indefinitely "open."

What may seem like a digression from our primary task should stand us in good stead for what is to come. The possibility for non-scientists' critical engagement lies in a recognition that science writers, as science writers, are writers first, scientists second. of course, there are many science writers who are scientists; but science writing, as we will see, is open to the same aesthetic, hermeneutic and logical criticisms and debates as is almost all narrative or so-called "creative" writing. We will also see that so much of the animosity among competing pop-science theories and pop-science writers is not, in fact, over the science itself, but over the metaphors and theoretical frameworks that have been built around common scientific "facts." The disagreements, in other words, are not fundamentally scientific, but aesthetic and, primarily, interpretive.

Despite much impressive philosophical work on metaphor, there is no one theory that can specify either the necessary and sufficient conditions of metaphor as such, or all the ways in which metaphors might mean. Where science writers argue over the appositeness of a particular metaphor, we will find that more thought needs to be given to just what metaphors are thought to be and how they are thought to function in the context of popular science. In light of the foregoing discussion, it will emerge that what is needed is not the theory of metaphor, but occasional theories for certain contexts of metaphorical occurrence. We will have reason to distinguish, in a rough, schematic way, between passing metaphors and concept metaphors, and between metaphors (or poetic metaphors) and models (or scientific metaphors).

\section{Metaphors and Models}

34 The problems of metaphor are particularly pertinent to the type of popular science that concerns us. Consider Richard Dawkins's and Mary Midgley's arguments over the notion of the selfish gene. The argument was, in one sense, over theory, but it hinged on the understanding of metaphor - what metaphor is, how it functions, how it is to be used - not on the understanding of what genes are.

Midgley objects to the use of "selfishness" as a metaphor for explaining gene activity. She objects because Dawkins himself characterizes his special, theoretical use of "selfishness" as a metaphor, but does not - to use one of Midgley's metaphors sufficiently "prune" this figure of its unusable branches (Midgley 1979, 447-48). A little more care with just how metaphors operate is needed, she argues. Note that in the following passage, context is all. Midgley begins by talking about metaphors in science writing; we must not take what follows as a commentary on metaphor in general:

To understand how metaphors can properly be used in scientific writing, we must get straight a fundamental point about the relation between metaphors and models. Every metaphor suggests a model; indeed, a model is itself a metaphor, but one which has been carefully pruned. Certain branches of it are safe; others are not, 
and it is the first business of somebody who proposes a new model to make this distinction clear. Once this is done, the unusable parts of the original metaphor must be sharply avoided; it is no longer legitimate to use them simply as stylistic devices. (Midgley 1979, 447; emphasis in original.) between metaphors and models, denotation and exemplification in Goodman are logically by asymmetrically related: "while anything may be denoted, only labels may be exemplified" (Goodman 1976, 57). Here, then, is what exemplification adds to our understanding of metaphor: labels can be exemplified by the things they denote, but they are not exemplified exhaustively (see Goodman 1976, 52-57). Replacing Midgley's metaphor/model relationship with that of denotation, exemplification, and coextensiveness, we can see that Midgley is quite right about metaphors, in the context of science writing, needing to be pruned. The possibilities for the metaphorical truthsorting of the ways in which our imagined lake might exemplify the various qualities of is a sapphire are broad; too broad, certainly, for the purposes of most, if not all, science writing. Genes are selfish, for example, must surely mean something rather well specified if it is to be scientifically instructive in the ways Dawkins wishes it to be. Both Goodman and Davidson believe that metaphor has its role in the advancement of knowledge (scientific or otherwise) (Goodman 1979, 125; Davidson 2006a, 210); but in the context of popular science and science writing, metaphors can hardly be left open to either the truth-/falsity-sortings of Goodman, or the individualistic meaning-as-affect formulation of Davidson. ${ }^{15}$ Equally, though, there is clearly something more than dealings in "dead" or "frozen" metaphors going on in the most interesting pop-science texts.

Before moving on, let us sketch some rough terminological distinctions. 
40 (1) Elsewhere, I have sought to replace the binary of dead and live metaphors with the non-binary distinction of passing and concept metaphors (see Belas, forthcoming). Passing metaphors are those the understanding of which requires little work, while concept metaphors are those on which understanding, or successful communication, depends, and which require some interpretive work.

41 Passing metaphors often, though not of necessity, take the form of verbs or adjectives: when, for example, Goodman writes that a metaphor that no longer excites interest or wonder "wilts" $(1979,127)$, he offers no sort of explanation of his metaphor; the presumption seems to be that none is needed. Similarly, Midgley, writing about science writing, does not feel compelled to explicate the meaning of "pruned," qua metaphor, even though she is writing of the importance of the metaphorical pruning of metaphors in science writing.

42 Concept metaphors are often, though not of necessity, nouns. Concept metaphors do require interpretive effort, and may evoke interest, wonder, even confusion. For concept metaphors to function appropriately in science writing, much of the interpretive work is done for the reader (see, for example, the analyses of selfish gene, gene selfishness, and spandrels below); that is, they are - or, pace Midgley, should be sufficiently pruned. Concept and passing metaphors are distinct from so-called "frozen" or "dead" metaphor and their - by extension - "liquid" or "live" counterparts for the simple reason that one speaker's idiom or cliché may - at least on first encounter - be another's metaphor, full of wonder, confusion, and possibility.

(2) Where Midgley presupposes but does not fully explain the difference between models and metaphors, I propose that "model" be understood as a certain use or application of metaphor. "Models," for our purposes, are the metaphors characteristic of science writing - those carefully "pruned," specified, or narrowed figures that Midgley seems to have in mind, the purpose of which is to clarify and illustrate. Models can be distinguished from the metaphors characteristic of poetry, which compress possible meanings into single figures and invite a wealth of interpretations. Poetic metaphor is not only to be found in poetry, but it is one mode by which Pound's notion of "language charged with meaning" is enacted (Pound 1934, 28).

Call the difference I have outlined the difference between metaphors, as such, and models; or, the difference between the metaphors (characteristic) of science, and those (characteristic) of poetry. The differences between these may not be categorical; but, like the metaphors most obviously characteristic of and appropriate to science writing, they offer a useful conceptual shorthand. With this rough difference in mind, we can ask questions like, how well does the notion of evolutionary "spandrels" fit, or map to, the model of architectural spandrels?; or, what refinements need to be made to the everyday meaning of "selfishness" in order for "gene selfishness" to do any useful theoretical work?

The following analyses of Dawkins and Gould are analyses not of poetic metaphor but of models. Our job is to assess the cogency of special, theoretical terms (such as "spandrels" and "selfishness") as models. The conceptual models used by Dawkins and Gould can ill afford, in the first instance, the free-associative openness of Davidsonian metaphor, or even the latitude of partial exemplification and truth-sorting of Goodman. However, while we are dealing with models, not poetic metaphors, I want to show that models can still have Rortyan redescriptive force. Models (or science metaphors) are not "dead" metaphors, but a variety of concept metaphor; they are not a different "species" of concept metaphor (different, say, from the concept metaphors 
encountered in poetry), but rather concept metaphors with generic conventions of use - namely, that their applicative range is tightly specified and explicated in advance; such is generally not the case with poetic metaphors. Indeed, by distinguishing between poetic and science metaphors, or metaphors and models, we are pointing to this generic-conventional distinction in concept metaphors. Later, we will see that one of the reasons Dawkins's concept of "gene selfishness" comes unstuck is a deficient understanding of metaphors and models; by contrast, we will find that Gould's model of evolutionary spandrels is far more clearly mapped to its architectural "original" than Dennett realizes.

\section{Dawkins and his Critics}

First and foremost, Dawkins's critics are exercised by his "metaphorical" choices, the effects of which are twofold: firstly, Dawkins's language has, for many, a political resonance which seems commensurate with a rugged individualism, a sense of society as an "arms race," 16 an all-against-all competition in which things just are the way they are and are no better than they can possibly be, for evolution always works towards optimal fitness. ${ }^{17}$ Secondly, the image of gene science itself which Dawkins's language presents us has been criticized. I will focus primarily on the second criticism, though one cannot avoid the first entirely; for a theorist of science like Rose (1997), language can both have ideologically invidious effects and be scientifically misleading.

With Dawkins's focus, particularly in his earlier works, almost exclusively on the gene as the fundamental unit of natural selection, both Midgley and Rose argue that Dawkins and other "ultra-Darwinists" misleadingly present a picture of the gene as atom-like an indivisible and ubiquitous basic unit - whereas, in fact, genes are variable in size, and are best understood in holistic, rather than atomistic, terms (Midgley 1979, 449, 450; Rose 1997, 216).

Rose also emphasizes the influence of expert or professional perspective on our preferred narratives (Rose 1997, 10-11). For example, rather than thinking in terms of one-to-one correspondences between single genes and their phenotypic expression, the biochemist will think in terms of genetic pathways and the emergence of characteristics (such as eye colour) due to the interactions of many chemical agents. This, claims Rose $(1997,115)$, is "the distinction between a developmental and genetic approach." Indeed, he states that "all biologists know" that this biochemical perspective is the more accurate description of genetic makeup and "behaviour," and that talk of a single gene "for x [...] is merely a convenient shorthand" (Rose 1997, 115). Rose dislikes that Dawkins recognizes this fact while insisting it does not matter "provided the system behaves as if such 'genes for' existed" (Rose 1997, 116).

Dawkins presents an idea of a federation of more or less independent genes doing what they are meant to do for their own good; so the very idea of "gene selfishness" is tied up with talk of "one gene for x." However, Midgley, like Rose, argues that Dawkins fails to acknowledge that in fact many genes are involved in indivisible phenotypic phenomena; this being the case, gene behaviour is surely better described as cooperative (Midgley 1979, 448-49). Already, then, we can discern what in our terms is a simplistically Rortyan programme, directed at the public rather than specialist sphere. Rose and Midgley attempt to spur a public shift of imagination, a thinking otherwise, from "genes are 'selfish' atoms" to "genes are cooperative networks." 
50 Along still similar lines to Rose, Midgley complains that Dawkins appears to acknowledge the variability of the gene while all the time writing about its immutability and permanence through space and time (Midgley 1979, 450): surely he cannot have things all ways. However, to accuse Dawkins, as Rose and Midgley do, of disseminating the gene-as-indivisible-atom image is somewhat misleading. Drawing on George Williams, Dawkins actually defines the gene as "any portion of chromosomal material which potentially lasts for enough generations to serve as a unit of natural selection" (Dawkins 2006, 28). And, responding directly to Midgley's criticism of The Selfish Gene, Dawkins attempts to clarify and correct: "I am not searching for an ideal, indivisible, atom-like unit. I am searching for a chunk of chromosomal material which, in practice, behaves as a unit for long enough to be naturally selected at the expense of another such fuzzy unit." (Dawkins 1981, 569, emphasis added.)

51 The disagreement between Dawkins, on one flank, and Rose and Midgley, on the other, is not really over basic definitions of the gene. Both Rose and Midgley believe that Dawkins shares - with them and the scientific community - the same basic understanding of what the gene is. But they believe, too, that this basic understanding and its clear expression are obscured by Dawkins's language. The points of contention are over: 1) whether or not the gene really is the basic unit of natural selection; 2) the most appropriate linguistic figures used to discuss this supposed unit. For Dawkins the basic unit is the single gene; for Rose and Midgley it is the organism, as talk of a single gene for $x$ may be convenient in some situations, but is ultimately inaccurate, even nonsensical (Midgley 1979, 448-49). Rose rejects Dawkins's revised dualism (the digital gene now takes the place of the "soul," travelling in the analogue husks we like to think of as our corporeal selves [see Rose 1997, 212-14]). His insistence on the language of cooperation (pressed, too, by Midgley) encapsulates his characterization of the organism as just that: a complex, integrated, cooperative system; a unit, rather than a federation of individual, and individualistic, genes. As examples, Rose looks to human sexual reproduction and the overproduction of sperm, and to the overproduction during brain development of neurons and synapses. The success of one (one sperm fuses with the ovum; one neuron-synapse connects with the dendrite of the target cell) in the face of vast overproduction might be interpreted in competitive terms. But the chances of one neuron and synapse, or a single sperm, succeeding if it were the only one may be slight (Rose, 1997, 143-53): if this is so, "cooperation," rather than "competition," may be a better model.

"Competition" may be misleading, particularly if not shorn of its demotic and economic connotations, for it fails to convey the sense of organismic harmony Rose wishes to promote and which he believes is the case. From Rose's perspective, to say that systems behave as if there is a gene for $x$ is to fudge the issue; systems do not operate as if this were the case; they cannot, because there is no such single gene for $x$. "Thinking of genes as individual units which determine eye colour may not matter too much," Rose $(1997,116)$ worries, "but how about when they become 'gay genes' or 'schizophrenic genes' or 'aggression genes'?" (Such one-to-one gene-phenotype reductionism, it is worth noting, also fails to explain sufficiently many of the most serious genetic illnesses [see Rennie 1994].) Note that we are talking here not of the cultural-political resonances of science metaphors, or models, but of cultural-political positions into which particular styles of the sciences' dissemination might play. So, although one gene for $x$ may be a convenient façon de parler, if it has clouded scientific thinking it is 
reasonable to think that in the context of popular science it will mislead many readers, who, as non-experts, may be particularly receptive to the models offered us.

\section{The Intentional Stance, Conceptual Clarity, and Selfish Genes}

For Midgley, "gene selfishness" is unworkable because genes are personified and treated as conscious agents. Even though, Midgley argues, Dawkins stresses several times that personification and talk of selfishness are just metaphorical conveniences, "selfish" can not impute conscious motives to genes. Even though Dawkins attempts to restrict and specialize the meaning of "selfish" as it extends to genes, he defines the gene as "[t]he fundamental unit of selection, and therefore of self-interest" (Dawkins 2006,11 , emphasis added). Midgley $(1979,451)$ responds, "he has linked the notion of self-interest quite gratuitously to a kind of subject for which it can make no sense at all. The only possible unit of self-interest is a self, and there are no selves in the DNA."

Midgley's argument is not entirely successful if one adopts the "intentional stance," from which we view a system "as if" it were "a rational agent" (Dennett 1997, 35-54). "Intentionality in the philosophical sense," Dennett summarizes, "is just aboutness. Something exhibits intentionality if its competence is in some way about something else." (1997, 39, 46-47; emphases in original.) Adopting the intentional stance, no necessary problems of selfhood, as posited by Midgley, arise from calling genes "selfish;" we are treating genes "as if" they are rational agents in order to make predictions about their "behaviour." Nevertheless, there are fatal problems with the selfish gene that have nothing to do with intentionality. There is a fundamental conceptual confusion, towards which Midgley gestures when she criticizes Dawkins for "mov[ing] from saying 'genes are selfish' to saying 'people are selfish"' (Midgley 1979, 448).

When Dawkins calls genes "selfish," he means to restrict and specialize this term. His "definitions of altruism and selfishness are behavioural, not subjective;" his definition of gene selfishness "is concerned only with whether the effect of an act is to lower or raise the survival prospects of the presumed altruist and the survival prospects of the presumed beneficiary." (Dawkins 2006, 4.) Earlier, however, Dawkins suggests, "a predominant quality to be expected in a successful gene is ruthless selfishness. This gene selfishness will usually give rise to selfishness in individual behaviour." $(2006,2$.)

Genes' "selfishness," then, is to be stripped of any moral or broadly cultural baggage; Dawkins is simply adopting the intentional stance. And as Rose points out, we must realize that Dawkins means to describe the behaviour of genes; he is not talking about genes for selfishness (Rose 1997, 201). But that he is not so speaking is, in a way, odd; the sociobiological perspective, with which Dawkins aligns himself (see Dawkins 1985), would seek or speculate as to the genetic bases of universal behaviours (see Wilson 2004). Here, the suggestion seems to be not that there are genes for selfishness, but that human selfishness is an extension of the special "selfishness" attributed to genes. Having restricted the meaning of gene selfishness, to suggest that the special selfishness of genes is somehow mirrored by humans' observable everyday selfishness is surely to upset the distinction, on which Dawkins insists, between the word's special and everyday meanings. 
57 A "human society based simply on the gene's law of universal ruthless selfishness would be a very nasty society in which to live," writes Dawkins. "Let us try to teach generosity and altruism, because we are born selfish." (Dawkins 2006, 3.) But Dawkins should not need this disclaimer, for it makes little sense if one takes seriously the conceptual distinction between the two selfishnesses (special, gene-level selfishness; everyday human selfishness). There need be no direct link between gene and human selfishness, but things get messy because Dawkins's denial that the two concepts are intrinsically linked - gene selfishness is "behavioural, not subjective" (Dawkins 2006, 4) - comes after two statements which suggest the opposite - "gene selfishness will usually give rise to selfishness in individual behaviour" (Dawkins 2006, 2); "[1]et us try to teach generosity and altruism, because we are born selfish."

Dawkins, then, suggests that his two selfishnesses are distinct, while moving between them as if the phenomenon of everyday, human selfishness were extrapolable from special, gene-level selfishness. At the same time, to add to the confusion, it would seem that "everyday selfishness" is supposed to provide the material from which the "gene selfishness" models is built and is made comprehensible:

At times, gene language gets a bit tedious, and for brevity and vividness we shall lapse into metaphor. But we shall always keep a sceptical eye on our metaphors, to make sure they can be translated back into gene language if necessary. (Dawkins 2006, 45.)

Dawkins fails to distinguish clearly between two quite different concepts for which he uses the same word. ${ }^{18}$ "Gene selfishness" is not adequately theorized, not rigorously enough separated from human selfishness, to be a sensible model. But, in a crucial sense, neither is everyday human selfishness clearly enough defined to be either a helpful point of contrast for, nor a basis from which we might model, "gene selfishness." Indeed, how could an emotivistic, and therefore rather fuzzy, notion one, that is, determined by cultural mores - provide such material or a benchmark, without a good deal of linguistic topiary?

Although the intentional stance vindicates, to some extent, Dawkins's talk of genes as if they are conscious agents, Midgley's dissatisfaction with "gene selfishness" as a metaphorical figure (or, in our further refined terms, model) still stands. In constructing our models, we must surely begin with literal, or "first," meanings, but the literal or everyday meaning of "selfish" is just what Dawkins is attempting to distinguish "gene selfishness" from. Dawkins needs a model by which something about gene "behaviour" and genetic phenomena can be specified and illustrated. What I am suggesting is that Dawkins's terms are still not sufficiently clear in and of themselves, nor has he sufficiently clarified and specified them, for this to be achieved. "Gene selfishness" is not cogent enough a model for us to determine what difference it makes to theory's conceptual store; it cannot, therefore, offer much in the way of Rortyan redescription: too much work remains to be done on what the concept is "about," what it means, in the first place.

61 The influence of The Selfish Gene, both as a work and for the central metaphor it introduced, cannot be gainsaid. "Three imaginary readers looked over my shoulder while I was writing," explains Dawkins: "the layman," "the expert," and "the student, making the transition from layman to expert." (Dawkins 2006, xxi, xxii.) Undoubtedly, The Selfish Gene and selfish genes have had a profound effect on the public understanding of genetics and evolutionary theory, and on "professional experts" in 
various fields. And Dawkins's first book has certainly created a great deal of debate among science commentators. This in itself is not insignificant, for it will remind those who read widely enough that science is creative, dynamic, and in many cases far from settled. But the cultural importance and influence of The Selfish Gene has nothing to do with its theoretical utility, and on this count, unfortunately, it does not offer much.

\section{Stephen Jay Gould: Adaptationism, Extrapolationism, Pluralism}

Dawkins and Dennett speak from and for what Gould calls the "adaptationist programme" - the view that natural selection is the only mechanism of change, and that all change is gradual and adaptive, conferring ever greater fitness on the organism. "We would not object so strenuously to the adaptationist programme," wrote Gould and Richard Lewontin in 1979, "if its invocation, in any particular case, could lead in principle to its rejection for want of evidence." Pervasive adaptation being virtually an article of faith, however, the possibility of non-adaptive change is not considered, and theorists are satisfied merely with "consistency with natural selection" (Gould \& Lewontin 1979, 588).

Interestingly, the demand for the possibility of falsification here is much like Popper's (2002) principle of demarcation of science and metaphysics: Gould and Lewontin's (as well as Rose's) aim has been to challenge what we might call the metaphysics of pervasive adaptation and natural selection. The mere fact that an event can be made to fit the theoretical mould prescribed by adaptationism does not mean that adaptationist theory is absolutely true - in the crude way that "true" is often used - or the best possible "fit" in all possible situations (or worlds). That events can be so moulded to theory merely illustrates Goodman's maxim that "Truth, far from being a solemn and severe master, is a docile and obedient servant." $(1978,18$.$) On occasion, Gould cites$ instances where writers of the adaptationist mindset admit that evidence supporting their views is wanting, and so assume that we simply haven't found the evidence yet; it must be there, somewhere, because we know adaptationism to be true. Much of Gould's energy was spent arguing that where such evidence is lacking, it is so not because we have missed it, but because it is not and never has been there at all (e.g., Gould 2007d; Gould \& Lewontin 1979). Gould's point at such moments is close to one made, in a different context, by Goodman: that, "[u]fortunately, dramatic violations often fail to disturb dogma” (Goodman 1978, 73).

For Gould, the "adaptationist programme" is one with the belief that natural selection is the only mechanism of evolutionary change worth considering. The idea that evolution consists in the accumulation, through natural selection, of micromutations leading to ever greater fitness - an asymptotic approach towards perfection - has led, Gould argues, to the conflation of the mechanism of natural selection with received notions of fitness, complexity, and progress. ${ }^{19}$ "Adaptationism," then, is closely allied with "extrapolationism," the belief that, natural selection being the only evolutionary mechanism worth studying, we can extrapolate from findings at one evolutionary level - the genetic - to all others. concepts in support of a pluralistic general theory of evolution. Evolution, Gould 
argued, is hierarchically ordered into several "tiers" of geological time, each tier with corresponding, dominant evolutionary mechanisms. Before we look closely at one or two key models in Gould's work, however, we need to consider just what the differing accounts of evolution are over which Gould and Dennett/Dawkins disagree. Adaptationism is one; but what of "extrapolationism," mentioned briefly above

Gould's is a theory of the severally tiered structure of evolution and its various mechanisms. Because he seems to decentralize natural selection (at the gene level especially), Gould has been accused of being anti-Darwinian (see Dennett 1995, 262-312). However, he emphasizes:

I [...] do not deny either the existence and central importance of adaptation, or the production of adaptation by natural selection [...] I do not deny that natural selection has helped us to explain phenomena at scales very distant from individual organisms [...] But selection cannot suffice as a full explanation for many aspects of evolution; for other types and styles of causes become relevant, or even prevalent, in domains both far above and far below the traditional Darwinian locus of the organism. (Gould, 2007b, 441-2, emphasis added.) ${ }^{20}$

At issue for Gould, then, are units and levels of selection: at levels other than that of the organism, mechanisms other than natural selection may play dominant roles. This is Gould's critique of "extrapolationism," the doctrine that all evolutionary change takes place first and foremost at the gene level, and that higher-level changes are simply "extrapolations" from there. This idea he aims to displace with his "Darwinian pluralism."

As far as Gould himself is concerned, then, no denial of Darwin, nor of the "central importance" - scientific or philosophical - of natural selection and adaptation. Neither does he see himself as being in disagreement with Darwin; one of Gould's favourite passages from Darwin is that in which the great man himself reminds his reader that "natural selection has been the main, but not the exclusive, means of modification." ${ }^{21}$ What Gould disagrees with is that natural selection is both the exclusive mechanism of evolutionary change and sufficient explanation of all life's complexity. Instead, he offers a hierarchical and pluralized model of evolutionary theory in which micro- and macro-evolutionary levels and mechanisms are "decoupled" from one another (Gould 1980b, 126): different mechanisms of change operate as the prime (but not necessarily exclusive) mover at each level. Think of Gould's attempt to offer several "decoupled" mechanisms as an attempt to offer a Goodman-esque model of many worlds within the universe of evolutionary theory; or, if one prefers a smaller scale, think of him as pointing to a plurality of languages spoken within the evolutionary world. Gould proposes "a general model of several rising tiers of time - with conventional Darwinian microevolution dominating at the ecological tier of short times and intraspecific dynamics; punctuated equilibrium dominating the geological tier of phyletic trends based on interspecific dynamics [...]; and mass extinction [...] acting as a major force of overall macroevolutionary pattern[.]" (Gould 2002, 88.)

You cannot extrapolate from gene to individual organism, Gould maintains, because "organisms are doing the struggling" (qtd Brockman 1995, 62). "Selection simply cannot see genes and pick among them directly," in significant part because organisms exhibit "emergent properties," the results of complex interactions of genes which are not, therefore, explicable in terms of single genes for $x$ (here, we return to Rose's territory) (Gould 1980a, 90)..$^{22}$ Natural selection, then, "must use bodies as an intermediary" (Gould 1980a, 90). Furthermore, argues Gould by means of a neat passing 
metaphor, we must not confuse "bookkeeping" and "causes." Because genes constitute the lowest evolutionary level, they will "record" all changes; higher-level selection will, of course, affect gene frequencies. But not all genetic changes will be felt at higher levels. So-called "neutral" substitution - molecular changes that are neither advantageous nor disadvantageous - is a case in point here. On this view, genes should not be portrayed (as they appear to be by Dawkins, Dennett, and other extrapolationists) as the only causal agents of evolutionary change. ${ }^{23}$

But, argues Gould, one cannot extrapolate from local populations of organisms to species, either. "The decisive step in evolution," he argues, is the macroevolutionary step from one species to another (Goldschmidt, qtd Gould 1980b, 125). This, he suggests, cannot be explained by gradual adaptation; species, to be recognizable as such, must achieve stability for an extended period of time, while speciation occurs over thousands rather than millions of years, a mere "moment" in geological/evolutionary time (Gould 2007d, 265). The geologically instantaneous break between species "requires another method than that of sheer accumulation of micromutations" (Goldschmidt, qtd Gould 1980b, 125). For speciation to occur, Gould insists, "reproductive isolation comes first and cannot be considered as an adaptation at all" because it is a random and unpredictable event $(1980 \mathrm{~b}, 124)$. "There is," Gould concludes, "a discontinuity in cause and explanation between adaptation in local populations and speciation; they represent two distinct, though interacting, levels of evolution." (1980b, 124.)

In Gould's evolutionary structure, no one level is reducible to another. In contrast, the extrapolationist account sees gene-level selection as the root of all change. But, to recap, Gould sees the adaptationist account as a confusion of causes and "bookkeeping:" all change will be recorded at the gene level by changes in gene frequency, but this does not prove that genes are the units being selected. Each of Gould's levels "interacts," as he says, with those above or below, but each level remains distinct, particularly as each tier is viewed not just in terms of the size of its units (the gene, the organism, the species, and so on), but also temporally; intra- and interspecies change, as well as change at even higher levels, occur at different speeds.

\section{"Greedy" Reductionism}

While Gould's theory does have plenty of room for the neo-Darwinist narrative, Gould does not believe that this gene-level, gene-centric narrative is sufficient to account for all evolutionary change at all levels. "The Darwinism of the modern synthesis," Gould writes, is "a one-level theory" that reduces all change to consequences caused by "struggle among organisms within populations" (2007c, 224). From the Dawkins/ Dennett perspective, all evolutionary phenomena should be traceable back (or down) to the gene level - a level even lower than that of the organism.

For Dennett, Gould's accusation of "reductionism," levelled at the neo-Darwinists, misses the point. Dennett $(1995,80-83)$ distinguishes between "greedy" reductionism the sort of short-sighted, sloppy reductionism of which, he thinks, we should be wary and the sort of reductionism characteristic of, even necessary to, good theorizing (where the job of theory is understood as simplification, and assisting in increasingly accurate prediction). It is, believes Dennett, this second reductionism that good neoDarwinism practises, but which Gould does not. Dennett's distinction, however, between reductionisms does nothing to clear up the dispute between our warring 
camps. It is easy enough to accuse Gould of being blinkered in his use of "reductionism;" but, with their staunch faith in the gene's-eye-view account of evolution, it is equally easy to accuse Dennett and Dawkins of precisely the "greedy" reductionism against which Dennett cautions us. As far as reductionism goes, both sides in the dispute may have identified chinks in their opponent's armour, but none big enough to admit a fatal blow.

Hopefully, all this will seem straightforward so far. But all I have done is to summarize some points of disagreement between two warring factions on the battlefield of evolutionary theory. This has been necessary because we need to know just what is being disputed, but also because, as we will see, Dennett fails to discredit, because he misreads, Gould.

We can, then, discern easily enough on what our warring factions disagree; but we lay readers are still no closer to being able to say who is right. Nor, though, are we likely to get much closer. Just why will become clear by article's end. First, we need a slightly closer consideration of some of Gould's key concepts, the supporting pillars on which his grand, pluralistic theory rests.

\section{Exaptations, Spandrels, and "Spandrels"}

"Exaptations" and "spandrels" are forms of "secondary" adaptation, modifications that arise not for present purpose (Gould \& Vrba 1982; Gould \& Lewontin 1979). "Exaptations" are adaptations that arose for one reason and were later coopted for another (such as the emergence of feathers for thermo-regulation; their later cooptation to flight) (Gould 2007c, 231-33). "Spandrels" are the necessary by-products, due to organisms' structural constraints, of adaptive changes that are themselves later used adaptively (the use by some but not all snail species of the shell's umbilicus for a brooding chamber, for example) (Gould 1997b). Dennett rejects the sense and use of "exaptations" and "spandrels:" even if one cannot say that particular features arose "for" their current use, surely it makes little sense to say that such features are not adaptive if one can say that the current uses to which the features are put are advantageous (Dennett 1995, 275-76). Further, Dennett $(1995,281)$ argues, secondary adaptations are accounted for by orthodox theory; adaptations always develop from prior structures that were once advantageous but are now obsolete.

Dennett goes to great lengths to dismiss "spandrels," in particular, by exposing what he sees as the idea's figurative deficiency. In architecture, spandrels are the triangular areas left over when an archway is built into a rectangular wall. In their famous spandrels paper, Gould and Lewontin begin by limning the ornately decorated structures that draw visitors to the Basilica di San Marco. Though these structures attract many visitors, the writers argue, they are there, in the first place, out of structural necessity: they are the unavoidable result of placing a circular-based dome on rectangularly arranged arches.

Dennett first argues that, strictly speaking, the structures to which Gould and Lewontin refer are pendentives; spandrels proper are the approximately triangular spaces left between adjacent archways running in line with one another. Dennett goes on to argue that pendentives are not necessary; other structures are available, such as the squinch 
(constructed by filling a square room's upper corners, thus forming an octagonal ceiling base) (Dennett, 1995, 271-73).

It is, of course, perfectly fair to scrutinize metaphorical "fitness." Midgley (1979) does just this when she criticizes Dawkins; and my criticisms of Dawkins have been based on what I see as the incoherence of his "gene selfishness." This incoherence arose in no small part because Dawkins seemed to want to distinguish gene selfishness from human selfishness, while all the time running the two together. But no such conceptual elision occurs with Gould and Lewontin's "spandrels." Odd though this suggestion may sound, there is a sense in which the word itself used to denote the concept Gould and Lewontin wish to introduce matters relatively little; for, if the concept of adaptation's necessary by-products is made both recognizable and definable, we can surely take our pick of shorthands: we are, after all, dealing with "spandrels" as a model in need of deliberate specification, rather than as a poetic metaphor. In our current context, the question to be asked is whether necessary structural by-products - call them "spandrels," "pendentives," or "squinches" - can actually be identified in biological structures, to which Gould answers "yes" (see Gould 2002, 1179-1295; Gould 1997b). As far as Dennett's criticisms go, we are talking about the difference between imperfect, even sloppy, terminology - on which count Dennett's criticisms surely stand - but a nonetheless coherent conceptual model - on which count they do not.

Strangely, too, there is a sense in which Dennett seems actually to make Gould's case for him. A dome placed on a circular base consisting of rectangularly arranged archways will produce pendentives. (In this model, the dome and the archways are "adaptations," the pendentives "spandrels" - necessary structural by-products later used "adaptively" as surfaces for decoration.) Squinches will produce an octagonal base; so they will necessarily produce a different structure. ${ }^{24}$ Architectural spandrels are indeed evolutionary spandrels in Gould's figurative sense, resulting unavoidably from the consecutive arrangement of arches in a wall. But so too are pendentives and squinches figurative, Gouldian spandrels. They, too, are structurally forced, necessary.

81 Moreover, when Dennett $(1995,281)$ argues that secondary adaptation is accounted for in his adaptationist orthodoxy, he appears to be playing to a dubious double standard: he rubbishes, on the one hand, Gould's concept of non-adaptive change; but on the other, where he can find a space, however small, for Gould's ideas, he suggests that adaptationism has already taken care of things. In doing this, Dennett simply ignores Gould's attempt to challenge the image of constant, gradual, progressive change. "Exaptation" and "spandrels" are key to a view of life in which success is marked by stability and is enjoyed by simpler rather than ever more complex organisms - a view very different from the one espoused by Dawkins and Dennett.

82 Dennett, then, has failed to demolish Gould's concept of evolutionary "spandrels." This evolutionary concept metaphor has been very clearly specified; so as a model - or science metaphor - the term is rather stable, regardless of any infelicities as far as first, or literal, meaning goes. With this concept, lay readers with scientific interests are hardly disadvantaged; they might, however, end up red-faced if, with Gould and Lewontin's paper tucked under their arms, they were to pronounce upon architectural matters at an architects' convention.

83 This case of evolutionary spandrels is informative: it shows us that models, or science metaphors, can be made to mean quite clearly even if labels' first meanings have been 
misapplied; but this can only be done if models' extensional ranges are carefully and precisely delimited before their free and easy use.

Gould's model of "spandrels" is coherent in a way that Dawkins's "gene selfishness" is not. A good thing, too, for it is one of the pillars on which Gould's grand view of evolution, one vastly different from what he sees as the reductionist orthodoxy of neoDarwinism, rests. Take "spandrels" away, and you have a much smaller, less sturdy theory. "Spandrels" encapsulates and - if they are identifiable in nature, as Gould and Lewontin believe they are - evidences non-adaptive change, itself a key theoretical feature of Gould's grand evolutionary theory. ${ }^{25}$ Indeed, non-adaptive change is posited in direct opposition to the neo-Darwinist narrative of untrammelled, gradual, "progressive" change. It is by chipping away at Gould's key concepts that Dennett hopes to discredit Gould.

Take "gene selfishness" away from neo-Darwinism, however, and you remove a decidedly unclear concept, but nothing more; you do not disprove the neo-Darwinist narrative. Indeed, Dawkins himself saw The Selfish Gene as adding to, or further clarifying, neo-Darwininst orthodoxy, not as launching a brand new evolutionary theory (see Dawkins 2006, xv, Ch.1). At most, he hoped that experts reading his book might find in it "a new way of looking at familiar ideas" (2006, xxi); but at base, claims Dawkins, "[t] he selfish gene theory is Darwin's theory" (2006, xv). I have not taken issue with Dawkins over his preferred grand narrative, but over the clarity, coherence, and theoretical utility of one of his key concepts.

\section{Punctuated Equilibrium}

Another Gouldian mechanism over which there has been much griping is "punctuated equilibrium," identified by Gould and Niles Eldredge (1977) as the phenomena of rapid change at the species level, followed by extended periods of stability. Although evolution is often thought of, diagrammatically, as a more or less smooth line representing constant, adaptive change through time, in fact, Gould argues, success is marked by overall stasis; lack of fitness forces rapid change and/or leads to rapid extinction. That the diagrammatically step-like pattern of punctuated equilibrium is dominant at the species level is, Gould contends, empirically supported: gradualists (those who believe in constant, gradual, micromutational change) are led, by virtue of the perspective they already have, to believe that apparent "jumps" between species suggest gaps in the fossil records. Gould argues, by contrast, that reliable records suggest that interspecies jumps or "saltations" (in terms of geological time) are precisely what we are dealing with (Gould \& Eldredge 1977; Gould 1980b; Gould 2007b).

Dennett rejects punctuated equilibrium on bare scientific and theoretical/conceptual grounds. In certain respects, he argues, punctuated equilibrium is just bad science. But where it does work, punctuated equilibrium can still be dismissed because the neoDarwinists got there first. For example, the step-like pattern Gould wishes to substitute for the smoother lines of the gradualists is already recognized by and implicit in the gradualists' representations: under higher "magnification," the gradualists' lines reveal themselves to be staircases (see Dennett 1995, 285-99). It is all a matter of scale; the gradualists' smooth lines represent overall change; the punctuationists' steps the small, logically necessary jumps between adaptations. 

equilibrium is a keystone in Gould's pluralized and hierarchical theory of evolution; punctuational patterns are the dominant pattern of evolutionary change at relatively high levels, not the necessary micro-structure of constant micromutation. "Punctuated equilibrium" is the name - call it a metaphor if you will; "model," given the foregoing discussion, is better - that Gould and Eldredge give to the phenomena that produce these patterns; it names a mechanism operating at a relatively high level of evolutionary unit and time.

So different are the Dennett-Dawkins and Gould positions, in fact, they do not theoretically cancel one another out. Certainly, Dennett's account - that punctuations can be seen in the fine-grained structure of the gradualist diagram - does not meet Gould head-on. Dennett changes the game, but does not beat Gould at his own. Gould wishes to incorporate ultra-Darwinism's basic tenets while rejecting what he sees as its reductionism, while Dennett wishes simply to dismantle Gould's theory. He fails to do so, however, because he either misses or dodges Gould rather than blocking or cancelling him.

It seems disingenuous, and a little crude, to suggest that the usable bits of punctuated equilibrium are already part of "orthodoxy," while bits deemed unusable are simply bad science. To do so is to suggest that one's opponent was partly right, but only because one got there first. To say this is to credit one's opponent with, at best, reiterating what has been said before, but less effectively than before. More importantly for us, though, such an approach as Dennett's ignores that Gould, in this case, has added to the language of evolutionary theory. It does not make sense to say of someone's coinage, "We developed that concept, we just didn't name it." It does not make sense because there can be no unnamed concepts. And yet, this seems to be Dennett's strategy with the element of "punctuation" he will allow into his narrative.

91 Dennett does not, overall, like the idea named by "punctuated equilibrium," but he has not really shown us what is wrong with it - what about it is confused, incoherent, or nonsensical - because he has argued around it. Moreover, the "punctuations" that Dennett does allow are so distant from Gould's that it makes little sense to say that Gould is simply making explicit in his work what is implicit in others'. Precisely because we are talking about new theory, models, concepts, it is equally senseless to suggest that "punctuated equilibrium" contributes nothing because it somehow lay dormant but unacknowledged or unnamed in orthodox theory. Dennett and Gould are talking about vastly different phenomena; but if we are to talk of "punctuated equilibrium," we can hardly do so while suggesting that those who conceptualized it have contributed nothing. Dennett's criticisms of "punctuated equilibrium" seem to rest on a misreading of Gould and Eldredge's model - what and how it means, what it names or denotes. It is easy enough to defend Gould and Eldredge, as I do, because they have, in Goodman's terms, "sold" this model in pretty clear and precise terms.

\section{Conclusion}

This article began with a problem: if a primary function of pop science is to take the scientific word to the masses (who do not have access to primary research and are not themselves research-active scientists), then how are engaged lay readers to choose between contradicting science narratives? Another way of phrasing this question is: 
given that pop science is written for the lay reader, how is this intended reader to gain a point of critical entry into the genre?

One way, I have suggested (and an important way at that), of taking part in a critical dialogue with pop science is to scrutinize the coherence and theoretical utility of particular works' central terms and concepts. This necessitated a consideration of the difficulties of theorizing metaphor, at the end of which a rough schematic was drawn up, in which science metaphors and poetic metaphors (or models and metaphors), and passing and concept metaphors were distinguished. A concept model or metaphor is theoretically useful if it offers something in the way of what Rorty calls "redescription;" or, it encourages, even forces, us to "think otherwise," to start reshaping our theories about the world.

My arguments against Dawkins's concept of "gene selfishness" turned on an attempt to show that it is too confused a concept model to be theoretically useful. If we cannot say with any certainty what a model models (that is, what a metaphor names or denotes), then it can offer little to our conceptual storehouse.

Crucially, my argument against Dawkins is an argument against the clarity, and therefore the utility, of his most famous term; it is no argument against the coherence, nor the "rightness" or "wrongness," of neo-Darwinism itself. To say that Dawkins's terms are not useful, then, is to say this: take away the concept of "gene selfishness," and the integrity of the neo-Darwinist narrative is hardly in danger. Quite the opposite, in fact, as you remove a decidedly confused, and therefore confusing, idea.

In this article, I have come down, unapologetically, in favour of Gould, precisely because those concepts of his that I have considered do have utility in the sense outlined above. "Punctuated equilibrium" and "spandrels" are keystones in his grand view of a pluralistic evolutionary structure. Without them, his edifice will crumble. These terms encapsulate structures (spandrels) or mechanisms (punctuated equilibrium) around which Gould's image of a "tiered" evolutionary structure is built. I have also defended Gould on the count of coherence: Dennett fails, I have suggested, to show how or why Gould's concepts do not work. All he manages to do - but this he does with great clarity and vigour - is tell us what his view of evolution is, and that he heartily disagrees with Gould (among others).

Why the pragmatist theoretical framework in all this? Firstly, it is not my suggestion that, in order to engage critically with popular science, one does not have to be a scientist so long as one is a pragmatist. Pragmatism - or, rather, the pragmatists on whom I have drawn - makes sense of the linguistic-metaphorical terms in which we might engage with popular science and a critique thereof. A pragmatist understanding of metaphor, and the difficulties of theorizing metaphor comprehensively, helps shine a spotlight on the central point of disagreement between science commentators like Midgley, Dawkins, Gould, and Dennett. As we have seen, the disagreement is rarely over scientific knowledge, per se, or definitions of such terms as "gene;" rather, it is over the models used to explore the organization and/or behaviour of such terms. The pragmatists I have turned to in this paper help justify the approach to popular science that I am advocating; but one does not have to be well-versed in Rorty, Goodman, and Davidson in order to take this approach - hence the structure of this paper, with a fairly stark division of theory and "case studies." 

conversation. Gould, I maintain, does ask us to think otherwise; his models are coherent and clearly specified - they are well "sold" - and the theory of which they are integral parts does stand in marked contrast to a view of evolutionary change that he, along with Rose, Dawkins, Dennett, and others, acknowledges as having achieved the status of orthodoxy. ${ }^{26}$ It is in creative response to the gaps in orthodox theory that Gould offers his models, which, pace Rorty and Goodman, re-make the linguistic world of evolutionary theory. Dawkins's lack of clarity does nothing to diminish the neoDarwinist narrative, but it cannot be said to have truly added to it or our conceptual storehouse. evolutionary science, can join a critical conversation, rather than be captive to a genre written, supposedly, for them. I have skirted the question "who's right?" by asking, instead, "who's coherent and theoretically useful?" But what of this first question: who's right?

In one of several exchanges between himself and Gould, and responding to an unfavourable review from Gould, Dennett (1997b, 64) writes: "John Maynard Smith praises my book [Dennett 1995]; Stephen Jay Gould attacks it. They are both authorities, but they can't both be right, can they?" This comment nicely encapsulates what has too long diverted some of pop science's better known disputants; indeed, it is just one comment in a protracted argument between the neo- or ultra-Darwinists and the Radical Science movement. ${ }^{27}$ I now want to make the perhaps unwelcome claim that, in a certain sense, there is very little for either the neo-Darwinists or Radical Scientists to be "right" about, in the context of pop science. I mean this in the following sense: assuming that the reader is a non-scientist, reliant on pop science for their scientific "literacy," the reader starts with the presumption that the pop-science writer believes the version of science they are offering. The reader is not in a position to do otherwise than start with the presumption that the "basic" science of a particular texts is "right" (think, for example, of the overall theoretical disagreement Midgley and Rose have with Dawkins, despite the three agreeing on the basic definition of "gene").

Coherence and utility, rather than "rightness," are, then, a more appropriate focus when engaging with popular science specifically. The writers we have been considering - writers whose works are read as populist educational texts and as exercises in science theorizing/philosophizing - should not make the mistake of thinking that their job is to tell us how the world just is. Their job, as popularizers and theorizers, is to clarify, and point out the pitfalls of, the best theories the scientific community has to offer about how it believes, to the best of its knowledge, the world just is.

Our best theories are those which seem to best, or better, describe and make predictions about the world; but, of course, it remains among scientists, philosophers, and other interested parties, a matter of contention as to how we decide the bases on which one theory is pronounced better than another. ${ }^{28}$ Clearly, this line of conversation lies outside the scope of this essay. But surely the contingencies and disputes that shape specialist fields of enquiry should equally shape and be present in discussions in the popular arena. To be "wrong" in the pop science arena, then, is to have failed to offer coherent second-order reports and clarifications of the sort mentioned above. Our interests in the utility of certain pop-science texts, and the basis of the disagreements we have considered, are then interpretive and, in a sense, aesthetic. 
103 My view of what popular science texts, written in the theoretical mode, should understand themselves as doing, then, and of what they have to offer their readers, is rather close to both Rorty's and Oakeshott's views about philosophy. Like philosophy, pop science can offer second order criticisms or clarifications of clusters of ideas, concepts, problems; but it must give up the idea that it is in the business of stating or discovering anything like firm, unassailable, immutable truths (Rorty 2009, 357-94; Oakeshott, 1991).

One option for the critically concerned reader of pop science is that we attempt to test the coherence and utility of certain arguments. As non-scientists, we are unlikely to be in a position where we can dispute the fundamental rightness or wrongness of certain theories. But we can chip away at the theories and models offered us, to see how robust they are. We might not be able to prove or disprove the neo-Darwinists' gene-centric view of life, but we can find problems in so influential a notion as the selfish gene without having to retrain as geneticists.

The view I offer of pop science, and, particularly, theoretical works in the genre, is that it is part of a conversation that takes place across boundaries of discipline and expertise. When not distracted by arguments over who was "right," Gould was perhaps better at this conversation than Dennett and Dawkins: rejecting the naturalistic fallacy, he would "draw no somber conclusions" from either neo-Darwinism or his own evolutionary theories, for he "[did] not believe [...] that the answer to moral dilemmas about meaning lies with the facts of nature, whatever they may be" (Gould 2007c, 235). (This contrasts markedly with Dawkins's claims about neo-Darwinism's capacity to answer the "big questions.") Repeatedly, Gould argued for "pluralism in guiding philosophies," for he accepted that "[g]radualism sometimes works well" (Gould 2007d, 266). However, given that "[w]e live in a world of enormous complexity," it is possible that more than one theory of evolutionary change might be needed if we are to avoid a "simplistic caricature and distortion of [Darwin's] theory." For Darwin, Gould reminded his readers, "cut to the heart of nature by insisting so forcefully that "natural selection has been the main, but not the exclusive, means of modification'." Accepting this, Gould asked, "[w] hy should such a complex and various world yield to one narrowly construed cause?" (Gould 2007b, 459.) Across Gould's work there is space for several theories of evolutionary modification; there must be if he is to make good his stated pluralism.

The concept metaphors and models characteristic of popular science can add to our common conceptual storehouse in profound ways, but the meanings of science writing's concept models must, in the first instance, be sufficiently specified and narrowed. If this is done, the way is prepared for later metaphorical and/or paradigmatic applications and extensions of those terms (cast your mind back, for example, to our earlier, passing mention of Dewey, who saw in Darwinian evolution a ready metaphor for the dynamics of cultural change). Midgley's pruning must take place initially, so that these arborescent things we call metaphors can grow all the more strong in later life, and withstand these later, broader - what we might call secondary - uses. 
In this article, I have attempted to show that, without recourse to specialist scientific knowledge, readers of pop science can ask - and perhaps even answer - questions about the coherence and utility of particular works. (This, I hope it is clear, is entirely different from simply asking whether works are difficult or not.) To ask such questions of pop science is of public importance, because - with the genre's defining function, the education of an engaged but non-expert readership, in mind - if a work is not coherent and theoretically useful in the ways we have been pursuing, then what good can it be to its intended reader?

My thanks to Professor Robert Eaglestone (for the informal conversations and friendly disagreements that marked the beginnings of this paper) and Professor Vincent Colapietro (for his invaluable advice during the essay's later stages of development).

\section{BIBLIOGRAPHY}

BELAS O., (forthcoming), "Metaphor and Literality After Davidson."

BRocKMAN J., (1995), The Third Culture: Scientists On the Edge, New York, Simon and Schuster.

DARWIN C., (2008), On the Origin of Species, Oxford, OUP.

DAVIDSON D., (1978), “What Metaphors Mean,” Critical Inquiry 5.1, 31-47.

DAVIDSON D., (1967), “Truth and Meaning," in The Essential Davidson, Oxford, OUP, 155-170.

DAVIDSON D., (1983), “A Coherence Theory of Truth and Knowledge," in The Essential Davidson, Oxford, OUP, 225-38.

DAVIDSON D., (1986), “A Nice Derangement of Epitaphs," in The Essential Davidson, Oxford, OUP, 251-65.

DAWKINS R., (2006), The Selfish Gene, Oxford, OUP.

DAWKINS R., (1981), “In Defence of Selfish Genes,” Philosophy 56 (218), 556-73.

DAWKINS R., (1999), The Extended Phenotype: The Long Reach of the Gene, Oxford, OUP.

DAWKINS R., (1985), “Sociobiology: The Debate Continues,” New Scientist (24 January), 59-60.

DAWKINS B. R. \& J. R. KREBS, (1979), “Arms Races Between and Within Species," Proceedings of the Royal Society of London, Series B 205.1161, 489-511.

DENNETT D., (1995), Darwin's Dangerous Idea: Evolution and the Meaning of Life, New York, Simon and Schuster.

DENNETT D., (1997a), Kinds of Minds: Towards an Understanding of Consciousness, London, Phoenix.

DENNETT D., (1997b), "Darwinian Fundamentalism: An Exchange," The New York Review of Books 44 (13), 64-65. 
DENNETT D., (2002), “Dan Dennett on Dangerous Memes," TED: Ideas Worth Spreading, (http:// www.ted.com/talks/lang/eng/dan_dennett_on_dangerous_memes.htm), Retrieved 13 April 2011.

DENNETT D., (2003), “Dan Dennett on Our Consciousness,” TED: Ideas Worth Spreading, (http:// www.ted.com/talks/lang/eng/dan_dennett_on_our_consciousness.html), Retrieved 13 April 2011.

DENNETT D., (2009), “Dan Dennett: Cute, Sexy, Sweet, Funny,” TED: Ideas Worth Spreading, (http:// www.ted.com/talks/lang/eng/dan_dennett_cute_sexy_sweet_funny.html), Retrieved 13 April 2011.

DERRIDA J., (1992), “The Law of Genre," in Acts of Literature, London, Routledge.

DEWEY J., (1997), “The Influence of Darwin on Philosophy," in The Influence of Darwin on Philosophy and Other Essays, New York, Prometheus Books.

EAgLeStone R., (2005), "Rhetoric and Ethics in Popular Science," Presented at Rhetoric, Politics, Ethics, Ghent University, 21-23 April, text provided by the author: (abstract: http:// www.rpe.ugent.be/Eaglestone.html), Retrieved 17 November 2009.

GOODMAN N., (1976), Languages of Art, Indianapolis, Hackett.

GOODMAN N., (1978), Ways of Worldmaking, Indianapolis, Hackett.

GOODMAN N., (1979), "Metaphor as Moonlighting," Critical Inquiry 6 (1), 125-30.

GOULD S. J., (1980a), “Caring Groups and Selfish Genes," in The Panda's Thumb: More Reflections in Natural History, New York, Norton.

GOULD S. J., (1980b), “Is a New and General Theory of Evolution Emerging?,” Paleobiology 6 (1), 119-30.

GOULD S. J., (1991), Wonderful Life: The Burgess Shale and the Nature of History, London, Penguin. GOULD S. J., (1994), “The Evolution of Life on Earth,” Scientific American (October), 85-91.

GOULD S. J., (1997a), “Darwinian Fundamentalism,” The New York Review of Books 44 (10), 34-37, (http://www.nybooks.com/articles/1151), Retrieved 11 March 2010.

GOULD S. J., (1997b), “The Exaptive Excellence of Spandrels as a Term and Prototype," PNAS 94 10750-55.

GOULD S. J., (2002), The Structure of Evolutionary Theory, Cambridge, MA, Belknap P, Harvard UP. GOULD S. J., (2007a), The Richness of Life: The Essential Stephen Jay Gould, London, Vintage.

GOULD S. J., (2007b), “More Things in Heaven and Earth,” in Richness of Life, 438-60.

GOULD S. J., (2007c), “Challenges to Neo-Darwinism and Their Meaning for a Revised View of Human Consciousness," in Richness of Life, 223-37.

GOULD S. J., (2007d), “The Episodic Nature of Evolutionary Change," in Richness of Life, 261-66. GOULD S. J. \& E. NILES, (1977), "Punctuated Equilibria: The Tempo and Mode of Evolution Reconsidered," Paleobiology 3.2, 115-51.

GOULD S. J. \& R. LEWONTIN, (1979), “The Spandrels of San Marco and the Panglossian Paradigm: A Critique of the Adaptationist Programme," Proceedings of the Royal Society of London, Series B, Biological Sciences, 205.1161, 581-98. 
GOULD S. J. \& E. VRBA, (1982), "Exaptation - A Missing Term in the Science of Form," Paleobiology 8.1, 4-15.

GOULD S. J. \& S. CONWAY MORRIS, (1998), "Showdown on the Burgess Shale," Natural History Magazine 107.10, 48-55.

KIMURA M., (1968), “Evolutionary Rate at the Molecular Level,” Nature 217, (17 February), 624-26.

KIMURA M., (1983), The Neutral Theory of Molecular Evolution, Cambridge, CUP.

MIDGLEY M., (1979), “Gene-Juggling,” Philosophy 54 (210), 439-58.

MIDGLEY M., (1983), “Selfish Genes and Social Darwinism,” Philosophy 58 (225), 365-77.

NATURAL HISTORY, Mission Statement, (naturalhistorymag.com/media-kit/mission-statement), Retrieved 13 April 2011.

OAKESHOTT M., (1991), "The Voice of Poetry in the Conversation of Mankind," in Rationalism in Politics and Other Essays, Indianapolis, Liberty Fund, 488-541.

POPPER K. P., (2002), The Logic of Scientific Discovery, London, Routledge.

POUND E., (1984), The ABC of Reading, Canada, Penguin.

QUINE W. V. O., (1963), From a Logical Point of View: Logico-Philosophical Essays, 2nd ed., New York, Harper \& Row.

RENNIE J., (1994), “Grading Gene Tests,” Scientific American (June), 88-97.

RORTY R., (1989), Contingency, Irony, and Solidarity, Cambridge, CUP.

RORTY R., (1998), Truth and Progress: Philosophical Papers, Vol. 3, Cambridge, CUP.

RORTY R., (2009a), Philosophy and the Mirror of Nature, Princeton, Princeton UP.

RORTY R., (2009b), "The Philosopher as Expert," in Philosophy and the Mirror of Nature, Princeton, Princeton UP, 395-421.

ROSE S., (1997), Lifelines: Biology, Freedom, Determinism, London, Allen Lane-Penguin.

ROSE S. \& H. ROSE (eds), (1976), The Radicalisation of Science: Ideology of/in the Natural Sciences, London, Macmillan.

ROSE S., Lewontin R. C. \& L. Kamin, (1990), Not In Our Genes: Biology, Ideology and Human Nature, London, Penguin.

SEARLE J. R., (1978), “Literal Meaning,” Erkenntnis 13 (1), 207-24.

SINCLAIR U., (2003), The Jungle, Tucson, AZ, See Sharp Press.

SMITH J. M., (1995), “Genes, Memes, and Minds,” The New York Review of Books 42 (19) (November 30), 46-48, (nybooks.com/articles/1703) Retrieved 12 February 2010.

SMITH J. M., DENNETT D. \& S. J. GOULD, (1993), “Confusion Over Evolution: An Exchange,” The New York Review of Books 40 (1/2), 43-44.

SOKAL A. (1996), "Transgressing the Boundaries: Toward a Transformative hermeneutics of Quantum Gravity," Social Text 46-47, 217-52.

WiLson A., (2011), "Peirce Versus Davidson on Metaphorical Meaning," Transactions of the Charles S. Peirce Society 47 (2), 117-35.

WILSON E. O., (2004), On Human Nature, Cambridge, MA, Harvard UP. 


\section{NOTES}

1. The model of conversation, and my privileging of it, here, over argument, is drawn from Oakeshott (1991).

2. In what follows, I have generally avoided argument rooted in favour of or discomfort with the supposed cultural politics of the writers in question. Not that such questions are unimportant; but such arguments have been made before, and look unlikely to be settled.

3. For an accessible, speculative overview of the relationship between the arts, sciences, and philosophy, see Rorty (2009b). On the impossibility of separating genres from one another, of keeping them "pure," see Derrida (1992).

4. In the passage to which I allude, Goodman makes the point that one does not argue for the truth of a categorial system, "since it has no truth-value, but for its efficacy in world-making and understanding. [...] For a categorial system, what needs to be shown is not that it is true but what it can do. Put crassly, what is called for in such cases is less like arguing than selling" $(1978,129)$.

5. This section draws heavily on arguments developed in greater detail in Belas (forthcoming).

6. On this point, Rorty (1989) and Goodman (1978) are close to one another.

7. "First meaning", as more or less synonymous with "literal meaning," is taken from Davidson (1986).

8. (3) differs from (2) in that it is not a case of misunderstanding, but rather of obscurity, ellipticality, ambiguity etc. on the part of the writer.

9. This idea, commensurate with Goodman (1978), is broad: it allows for someone who is bilingual or polyglot, and also for someone who is, say, both a scientist and an artist.

10. See Goodman $(1976,68-74 ; 1979)$.

11. On symbolic systems, or worlds, see Goodman (1978).

12. On the importance of context, or "background assumptions" (Searle), to meaning, see Davidson (1986) and Searle (1978).

13. Of course, metaphorically or literally are not the only ways in which sentences might be said or intended. The point here is to do, again, with this fuzzy notion of context. Communication succeeds if we realize that a sentence is uttered ironically, metaphorically, angrily, and so on; it fails if we do not realize such ways and styles of utterance.

14. In Macbeth II.ii, following the murder of Duncan, Macbeth reports his imagined hearing of "Sleep no more! | Macbeth does murder sleep." In this context, the claim "Macbeth is a murderer" might be considered both literally and metaphorically true. Things are not complicated by the fact that Shakespeare's Macbeth is a fictionalized character (on this, see Goodman 1976, 21-26).

15. See also Wilson (2011) on the difference between causation and content in metaphorical expressions.

16. See chapter 4, Dawkins (1999, 55-80); Dawkins and Krebs (1979). For critiques, see Rose (1997); Rose and Rose (1976); Haraway (1991, 217-21); Midgley (1979), (1983). For statements and defences of Dawkins's position, see especially Dawkins (2006), (1981), (1999).

17. This is the "Panglossian Paradigm" (see Gould and Lewontin [1979]; Rose [1997, 230-37]).

18. . That Dawkins also views the use of metaphor as a (metaphorical?) "lapse" contrasts informatively with the more serious views of metaphor taken by Rorty, Goodman, and Davidson.

19. Gould makes this and related rguments often. See, for example, Gould (2002), (1980), (1994), (2007b); Gould and Lewontin (1979). Sections II and III in Gould (2007a) provide an excellent overview of Gould's evolutionary theories.

20. For criticism of Gould, see Maynard Smith, Dennett, and Gould (1993); Dennett (1997b).

21. Darwin $(2008,8)$. See, e.g., Gould (2007b, 438; 1994, 85; 2002, 147, 254), Gould \& Lewontin (1979, 155).

22. For Gould on emergent properties, see Gould (1980b). 
23. See Gould (2007c, 233); Smith, Dennett, \& Gould (1993). Kimura's (1968; 1983) theory of neutralism is crucial to Gould's critique of genetic fundamentalism.

24. See Rose's defence of spandrels (Rose, 1997, 235-57).

25. The importance of non-adaptive change to Gould's grand theory, as Gould himself understood it, is indicated by the space it gets in his formidable Structure of Evolutionary Theory (2002): chapters 9,10 , and 11 , which deal with mechanisms and phenomena of non-adaptive change, take up some 550 pages of this roughly fourteen-hundred-page work.

26. See, passim but especially Part III, Gould (2007); Rose (1997, vii-xii); Dawkins (2006, xv, Ch.1); Dennett (1995, passim).

27. The literature on the ideological, philosophical, and scientific disputes between the neoDarwinists and Radical Science movement is substantial. However, refer to the following: Dawkins (1981; 1985; 2006, especially the final endnote, page 331-32); Dennett (1995, especially the chapter on Gould; 1997b); Gould (1997a; 2007b; 2007c), and the editors' introductions to Gould (2007); Rose (1997), throughout but especially his introduction; Rose and Rose (1976); Rose, Lewontin, Kamin (1990); Smith (1995); Smith, Dennett, Gould (1993). For a warning against the uncritical, wholesale "culturalization" of science, see, of course, Sokal (1996).

28. This dispute hinges, in part, on debates between realists and anti-representationalists, and arguments as to how or if language hooks onto the world. The issue is complex, but good introductions may be found in a number of Rorty's (1998) essays, especially his extended commentary on Dennett (98-121).

\section{AUTHOR}

OLIVER BELAS

Chingford Foundation School, London UK

olibelas[at]gmail.com 